\title{
ajankohtaista
}

\section{VIETS-kevätseminaarista lyhyesti}

Eri tavoin rakentuvat ja tuotetut mielikuvat ja todellisuudet Venäjästä ja Euroopasta olivat Venäjän ja Itä-Euroopan tutkimuksen seuran (VIETS) vuotuisen kevätseminaarin teemana Tieteiden talolla Helsingissä 10. toukokuuta. Kevätseminaari on seuran vakiintunut tapahtuma, jossa ajankohtaisen tutkimuskeskustelun lisäksi julkistetaan vuosittaisen Pro gradu -kilpailun tulokset. Tänä vuonna juhlistimme myös seuran 30-vuotista taivalta. Puheenjohtaja Joni Virkkunen avasi tapahtuman kertomalla seuran perustamisesta syksyllä 1989 nimellä "Neuvostoliiton ja Itä-Euroopan tutkimuksen seura". Nykynimensä mukaisesti seura edistää Venäjän ja Itä-Euroopan tutkimusta ja julkaisee Idäntutkimus-lehteä, joka on ainoa alan suomenkielinen julkaisu.

Seminaarin pääpuhujina esiintyivät kulttuurin ja yhteiskunnan tutkijat Olga Davydova-Minguet (Karjalan tutkimuslaitos, Itä-Suomen yliopisto), Sigrid Kaasik-Krogerus (Musiikin, taiteen ja kulttuurin tutkimuksen laitos, Jyväskylän yliopisto) ja Kaarina Aitamurto (Aleksanteri-instituutti, Helsingin yliopisto). He pohtivat eri näkö- kulmista, kuinka menneisyydestä neuvotellaan ja kuinka kansallista ja transnationaalia muistia ja kulttuuria rakennetaan menneisyyden esitysten varaan Venäjällä ja Euroopassa. Esimerkkeinä näitä kysymyksiä valottavista tutkimuskohteista toimivat Venäjän ja Suomen näkemykset toisesta maailmansodasta ja Venäjän Karjalan vankileireistä, eurooppalainen kulttuuriperintötunnus sekä Venäjän vähemmistöuskontojen, erityisesti niin sanotun "perinteisen islamin" hallinta.

Näitä puheenvuoroja seuranneessa paneelikeskustelussa pohdittiin ja muisteltiin Venäjän ja Itä-Euroopan alan tutkimusta Suomessa sekä seuran ja Idäntutkimus-lehden toimintaa. Paneeliin osallistuivat VIETSin entiset puheenjohtajat Kimmo Kääriäinen ja Katalin Miklóssy sekä Idäntutkimuksen entinen päätoimittaja Markku Kangaspuro ja nykyinen päätoimittaja Katja Lehtisaari. Paneelissa todettiin muun muassa, että VIETSin rooli tutkimuksen edistämisessä on ollut merkittävä, koska se keskittyy eri tieteenalojen välisiä rajoja ylittävään aluetutkimukseen näin vahvuutenaan monitieteisyys. Monitieteisyys ja tutkimuksen edistäminen

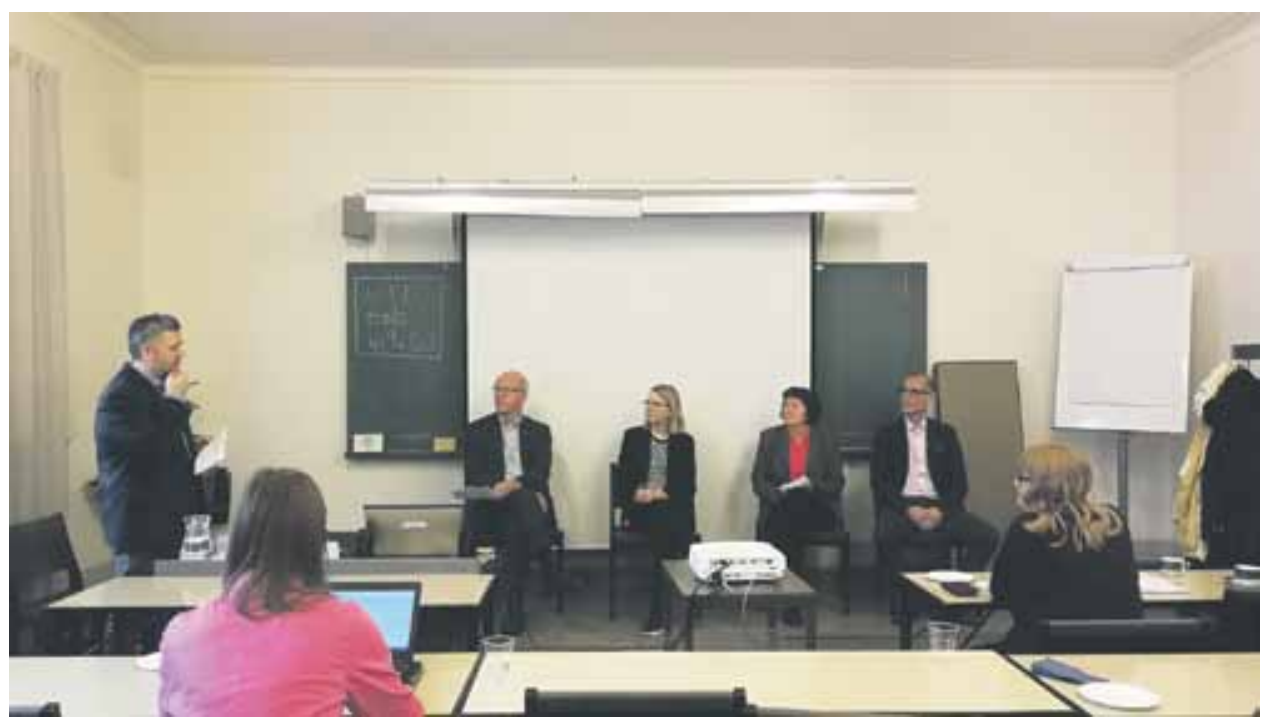

Seminaariin paneelikeskusteluun osallistuivat Kimmo Kääriäinen, Katja Lehtisaari, Katalin Miklóssyja Markku Kangaspuro. Keskustelua johti VIETSin puheenjohtaja Joni Virkkunen. Kuva: Olga Hannonen 
katsottiin myös Idäntutkimuksen valteiksi. Lisäksi Idäntutkimuksen rooli nuorten tutkijoiden julkaisutoiminnan ja uran edistämisessä voidaan nähdä erityisen tärkeäksi. Esimerkiksi Pro gradu -palkinnon saaja voi julkaista opinnäytteeseensä pohjautuvan artikkelin lehdessä.

VIETS palkitsee vuosittaiseen kilpailuun ilmoitetut edeltävän vuoden parhaat Venäjää ja Itä-Eurooppaa käsittelevät pro gradu -tutkielmat. Tänä vuonna kilpailun voitti Lisa Gohlke. Hänen yhteiskuntamaantieteen alaan kuuluva tutkielmansa "People Believe in What They Want to Believe: Myriad Ways to Embed the RomanianMoldovan State Border in Collective Identities in Everyday Life" valmistui Itä-Suomen yliopiston kansainvälisestä Border Crossings -maisteriohjelmasta. Työ käsittelee kollektiivisia identiteet- tejä ja arkea yhdellä kiinnostavalla, mutta varsin vähän tutkitulla Romanian ja Moldovan rajaalueella Kaakkois-Euroopassa. Kilpailun toisen palkinnon sai Jarkko Hietala. Hänen tutkielmansa "Kuoleman laaksossa: prosessijäljitysanalyysi julkisen sitoumuksen vaikutuksesta Krimin sodan diplomatiassa" valmistui Tampereen yliopiston Johtamiskorkeakoulun politiikan tutkimuksen tutkinto-ohjelmasta. Hietala tarkastelee työssään 1800-luvun turvallisuusjärjestelmän muutosta ja suurvaltojen välisiä suhteita Krimin sodan esimerkin kautta. Onnittelut vielä kerran palkituille! Seminaarin päätteeksi nostimme maljan 30-vuotiaalle seuralle.

Olga Hannonen \& Minna Piipponen

\section{Akateemisena vanhempana BASEES-konferenssissa 12.-14.4.2019}

Berliinin muurin murtumisesta tulee marraskuussa kuluneeksi kolmekymmentä vuotta. Muurin murtuminen ja kommunismin kaatuminen olivat tänä vuonna Britannian Slaavilaisen ja ItäEuroopan tutkimuksen yhdistyksen (British Association of Slavonic and East-European Studies, BASEES) järjestämän konferenssin pääteema. Myös Baseesissa puhalsi pienimuotoinen wind of change, mikäli konferenssia tarkastelee tieteidenvälisestä ja perhepoliittisesta näkökulmasta.

Sain helmikuussa 2019 kutsun Baseesin monivuotiselta presidentiltä, Oxfordin yliopiston emeritaprofessori Judith Pallot'lta pitää puheenvuoron neuvostoliittolaisten muusikkojen reaktioista Berliinin muurin murtumiseen konferenssin pääpaneelissa avajaispäivänä 12.4.2019. Sanoin heti, etten matkusta ilman vuoden ikäistä poikaani. Cambridgessa vuosittain järjestettävää konferenssia on kritisoitu siitä, ettei se ota huomioon perheellisiä. Lapsilla ei ole tähän mennessä ollut lupa yöpyä järjestävän collegen kampusalueella. Basees teki kuitenkin yllättäen uuden linjauksen ja lapsestani tuli konferenssin pioneeri ja koehenkilö. Miksi? Pahat kielet sanoisivat, että Brexit tekee epätoivoiseksi, mutta todellinen syy on varmaankin sangen käytännöllinen.

Basees kykenee uudistumaan juuri nyt, koska konferenssin pitopaikka on vaihtunut. Konferenssi järjestettiin aiempina vuosina Fitzwilliam Collegessa, jonka säännöt kielsivät lasten yöpymisen kampuksella. Britanniassa monissa yliopistoissa on samanlaiset käytännöt. Kyse on useimmiten puutteellisista vakuutuksista ja siitä, ettei kampuksia ole suunniteltu lasten käyttöön. Säännöt tuottavat kuitenkin ongelmia akateemista uraa tekeville perheellisille ja professori Pallot pahoitteli, että käytäntöjä parannetaan Baseesin osalta vasta nyt. Robinson College, jossa Basees kokoontui nyt ensimmäisen kerran, on huomattavasti lapsiystävällisempi ja varastossa on jopa vauvan retkisänkyjä (Akateemisen vanhemman kannattaa kuitenkin varautua siihen, että lapsi saattaa tästä huolimatta valita juuri sinun sänkysi).

Entä minkälaista on matkustella työasioissa yksin pienen lapsen kanssa? Matkaa taitettiin lapsi rintarepussa, takana oli pelkästään huonosti nukuttuja öitä ja päiväkodista oli tarttunut ärhäkkä flunssa. Olisiko kannattanut kieltäytyä konferenssin pääpuheenvuorosta? Osallistumiseeni konferenssiin vaikutti suuressa määrin halu tuoda oman oppiaineeni ja erityisalani näkökulma esille suurelle monitieteiselle yleisölle, kun siihen kerrankin tarjoutui kunnon mahdollisuus. Monitieteisten konferenssien ongelmana on edelleen akateeminen lokeroituminen. Yhteiskuntatieteilijät tulevat harvemmin kuuntelemaan taiteentutkimuksen paneeleja. Etenkin musiikintutkimusta pidetään edelleen liian haastavana erityisalueena. Syy on myös osittain musiikkitieteilijöissä, joiden on opeteltava puhumaan musiikista ymmärrettävästi monitieteisellä areenalla. Pääpuheenvuorojen kohdalla muiden tieteenalojen edustajat eivät voi 